University of Montana

ScholarWorks at University of Montana

$12-2011$

\title{
Lack of Fire Has Limited Physiological Impact on Old-Growth Ponderosa Pine in Dry Montane Forests of North-Central Idaho
}

Eric Keeling

Anna Sala

University of Montana - Missoula, sala@mso.umt.edu

Thomas H. DeLuca

Follow this and additional works at: https://scholarworks.umt.edu/biosci_pubs

Part of the Biology Commons

Let us know how access to this document benefits you.

\section{Recommended Citation}

Keeling, Eric; Sala, Anna; and DeLuca, Thomas H., "Lack of Fire Has Limited Physiological Impact on OldGrowth Ponderosa Pine in Dry Montane Forests of North-Central Idaho" (2011). Biological Sciences Faculty Publications. 318.

https://scholarworks.umt.edu/biosci_pubs/318

This Article is brought to you for free and open access by the Biological Sciences at ScholarWorks at University of Montana. It has been accepted for inclusion in Biological Sciences Faculty Publications by an authorized administrator of ScholarWorks at University of Montana. For more information, please contact scholarworks@mso.umt.edu. 


\title{
Lack of fire has limited physiological impact on old-growth ponderosa pine in dry montane forests of north-central Idaho
}

\author{
Eric G. Keeling, ${ }^{1,3}$ Anna Sala, ${ }^{1,4}$ and Thomas H. Deluca ${ }^{2,5}$ \\ ${ }^{1}$ Division of Biological Sciences, University of Montana, Missoula, Montana 59812 USA \\ ${ }^{2}$ Department of Ecosystem and Conservation Sciences, University of Montana, Missoula, Montana 59812 USA
}

\begin{abstract}
Reduced frequency of fire in historically fire-adapted ecosystems may have adverse effects on ecosystem structure, function, and resilience. Lack of fire increases stand density and promotes successional replacement of seral dominant trees by late-successional, more shade-tolerant species. These changes are thought to increase competition for limited resources among trees and to increase physiological stress of dominant, fire-adapted species. However, there has been little effort to directly investigate effects of lack of fire on the physiological status of old trees, especially in unlogged, protected forests. At four remote sites in the Selway-Bitterroot region of Idaho, we tested whether the physiological status of dominant old-growth ponderosa pine trees in repeatedly burned stands (three to four 20thcentury wildfires at roughly historical fire frequency) differs from trees in paired stands not burned for at least 70 years. We hypothesized that trees in relatively unburned stands would exhibit signs of physiological stress due to increased competition for resources in higherdensity stands. Needle chemistry and morphological variables, fine root production, mycorrhizal infection rates, depth of soil water resources, and recent basal area growth rates were measured as indictors of competition-induced stress. Contrary to predictions, needle carbon isotopic ratio $\left(\delta^{13} \mathrm{C}\right)$ and fine root production, variables related to water stress, were slightly higher in repeatedly burned stands driven by site-specific responses, and there were no significant biological differences between trees in repeatedly burned stands vs. stands unburned for at least 70 years in the remaining variables. Our results raise the possibility that dominant ponderosa pine trees in uneven-aged forests may be more resilient to increased stand density associated with the lack of fire than previously thought. If so, our results have implications for the management of uneven-aged, old-growth forests.
\end{abstract}

Key words: fire exclusion; fire suppression; old growth; physiology; Ponderosa pine; resilience; succession; unmanaged forests.

\section{INTRODUCTION}

Reduced frequency of fire in historically fire-adapted ecosystems is thought to have adverse effects on ecosystem structure, function, and resilience (Arno and Fiedler 2005). In the western United States, ponderosa pine (Pinus ponderosa) forests are a widespread landscape feature that historically experienced relatively frequent fire, although specific fire regimes vary across the range (Oliver and Ryker 1990, Veblen 2003, Schoennagel et al. 2004). In low-severity and mixed-fire regime forests of the inland northwestern United States, ponderosa pine is considered an early successional, or seral, dominant, maintained by fires that reduce shadetolerant, later successional competitors such as Douglasfir (Pseudotsuga menziesii) or grand fir (Abies grandis)

Manuscript received 16 June 2010; revised 1 March 2011; accepted 20 April 2011. Corresponding Editor: D. McKenzie.

${ }^{3}$ Present address: Cary Institute of Ecosystem Studies, Millbrook, New York 12545 USA. E-mail: keelingeric@gmail.com

${ }^{4}$ Corresponding author. E-mail: sala@mso.umt.edu

${ }^{5}$ Present address: College of Natural Resources, Bangor University, Bangor, Gwyneed LL57 2UW United Kingdom.
(Pfister et al. 1977, Steele et al. 1981, Oliver and Ryker 1990). Stand densities and the densities of shade-tolerant competitors have increased in many ponderosa pine stands that have not burned at historical frequencies (Arno 1988, Agee 1993, Covington and Moore 1994a, Keane et al. 2002, Fulè et al. 2004, Keeling et al. 2006). However, recruitment increases after grazing (Bakker and Moore 2007) or logging (Naficy et al. 2010) may also contribute to these changes. These density and species changes are considered anthropogenic, because the cessation of frequent fire is largely a result of over a century of fire-suppression policies. The effect of lack of fire on mature and old-growth ponderosa pine forests is of particular interest and concern because of the value and relative rarity of these forests (Kolb et al. 2007).

In the absence of fire, higher stand densities and increased competition for resources are thought to induce physiological stress in mature ponderosa pine trees, increasing mortality risk and the probability of severe fire (National Fire Plan 2001 [as cited in Veblen 2003]; Skov et al. 2004, Wallin et al. 2004, Arno and Fiedler 2005, Sala et al. 2005, Kolb et al. 2007, Fettig et al. 2007). However, effects of lack of fire on mature trees 
are poorly understood for several reasons. First, negative effects of fire deficiency on trees are commonly inferred from measured positive effects of various fire surrogate treatments, usually thinning or combined thinning/prescribed burning treatments (Donner and Running 1986, Kolb et al. 1997, Feeney et al. 1998, Stone et al. 1999, Latham and Tappeiner 2002, Wallin et al. 2004, Sala et al. 2005). However, it is not clear that inferences from such studies are valid for predicting consequences of reduced fire frequency in relatively undisturbed forests because thinning and prescribed fire treatments are generally implemented with the goal of reducing harm to mature trees. Therefore the severity of negative effects such as heat damage to needles, buds, cambial cells, and fine roots (Agee 1993) may be greater in natural wildfire than from fire surrogate treatments. In any case, the short time scale of many fire surrogate studies does not allow for the observation of the longterm balance of positive and negative responses. Second, long-term studies of growth in fire-excluded stands (Sutherland 1983, Biondi 1996) generally lack parallel measurements in nearby repeatedly burned control stands. Finally, because recruitment after logging may increase stand density over and above increases in unlogged stands (Laudenslayer and Darr 1990, Kaufmann et al. 2000, Stephens 2000, Naficy et al. 2010) there is a need for studies in unlogged forests in order to separate effects of fire-exclusion from confounding effects of previous logging. For these reasons, the assumption of higher physiological stress in trees in unburned stands requires further testing.

If trees experience higher physiological stress due to competition in the absence of fire, a series of responses on biochemistry, morphology, and growth characteristics of leaves, roots, and stems are expected. Needle chemistry (percent $\mathrm{N}, \mathrm{C}: \mathrm{N},{ }^{13} \mathrm{C}:{ }^{12} \mathrm{C}$ ) provides an integration of the tree's nutrient and water status. Needles of trees experiencing competition-induced stress are expected to have lower percent $\mathrm{N}$ (Feeney et al. 1998, Stone et al. 1999, Wallin et al. 2004), higher C:N ratios (Waring and Schlesinger 1985), and higher C isotopic ratio $\left(\delta^{13} \mathrm{C}\right.$ ) (Adams and Kolb 2004, Wallin et al. 2004), the latter due to reduced discrimination against the heavy $\mathrm{C}$ isotope when stomata are closed during periods of water stress. Values of basic needle growth characteristics (average needle length, total needle biomass) are also expected to decrease for trees with increased competition-induced stress (Feeney et al. 1998, Stone et al. 1999) although these factors will also be affected by the relative overall biomass allocation to leaves. Similarly, trees experiencing insufficient water and nutrient resources are expected to have longer-lived needles, lower leaf specific area (Reich et al. 1997), more fine roots (Vogt et al. 1983, Gower et al. 1992), higher mycorrhizal infection rates (Smith et al. 2005), and tap deeper water sources (detectable by comparing hydrogen isotopic signatures in xylem water to soil water samples). Finally, stemwood (basal area) growth is expected to decrease in the absence of fire if competition reduces overall resource availability.

There is great interest in the perpetuation of old ponderosa pine forests because of their ecological, scientific and cultural value (Kolb et al. 2007). Restoration of these forests often focuses on returning stands to their pre-settlement densities and commonly assumes that old trees in denser stands that have not experienced frequent fire are under stress. However, this assumption has rarely been tested which was the goal of this study. We sampled old-growth ponderosa pine trees in paired stands at four remote sites in Idaho, USA. Each pair consisted of a stand that had not burned for at least 70 years ("unburned") and a stand which burned at roughly the historic fire-frequency during the 20th century including a recent fire 12-17 years before sampling ("repeatedly burned"). We ask the question: Do old-growth ponderosa pine trees in relatively unburned stands show signs of competition-induced stress compared to trees in repeatedly burned stands? Because previous results from a larger study that included these sites showed significantly higher stand densities (Keeling et al. 2006) and lower available N (DeLuca and Sala 2006) in unburned stands overall, we expected to find evidence of competition-induced physiological stress in unburned stands.

\section{Methods \\ Site selection}

In 2003, a total of seven remote study sites were located in unlogged, mid-elevation ponderosa-pine-Douglas-fir forests within or on the periphery of wilderness areas in Idaho (see DeLuca and Sala [2006] and Keeling et al. [2006] for site selection details). For logistical reasons, four representative sites were chosen for the more intensive sampling needed for this study (Fig. 1). A weather station central to these sites reports mean January high temperatures of $1.4^{\circ} \mathrm{C}$, mean July high temperatures of $27.2^{\circ} \mathrm{C}$, and mean annual precipitation of $76.2 \mathrm{~cm}$. This region is generally characterized as having a mixedseverity fire regime (Heyerdahl et al. 2008).

At each of the four sites, a relatively unburned stand was compared to a repeatedly burned stand. The four "unburned" stands had not experienced fire for $>124$, 90,85 , and 70 years, respectively. Note that in this paper, "unburned" means not burned after 1934, but two out of four of stands labeled "unburned" had one recorded wildfire before 1934, and one stand had two recorded fires. In contrast, repeatedly burned stands experienced three to four 20th-century wildfires at intervals ranging from 6 to 58 years (mean $=34$ years) with the most recent fire 12-17 years before sampling. Although the two groups of stands are clearly distinct based on the criterion of time since fire, the labels "unburned" and "repeatedly burned" are not meant to imply uniform exposure to fire or time-since-fire within each category. Tables 1 and 2 show environmental data fire history, ages of trees sampled, and stand densities, 

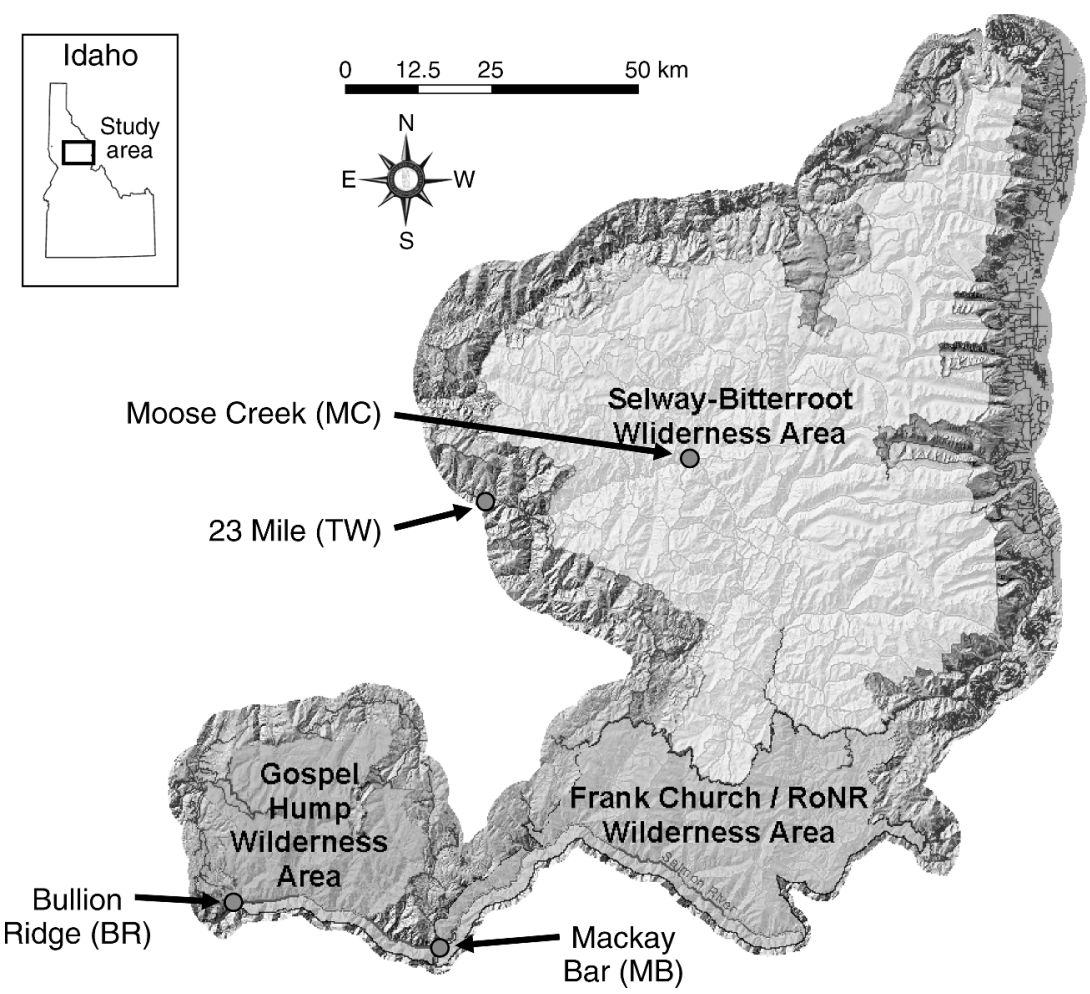

FIG. 1. Study area and site locations in northern Idaho, USA (RoNR = River of No Return).

for all stands. Density estimates for each stand were based on measurements in three plots per stand (see Keeling et al. 2006). Although some physiographic differences between stands existed, on average there were no systematic physiographic differences between unburned and repeatedly burned stands from each site across the entire study (paired $t$ tests comparing slope, aspect, and elevation, $P<0.05$ ). Fire histories for all stands were based on U.S. Forest Service fire maps, field reconnaissance, and on-site fire scar analyses (see
DeLuca and Sala 2006 and Keeling et al. 2006 for more detailed methods on fire histories). Note that the last fire was $12-17$ years before the study was initiated; therefore measurements are not short-term responses to fire. We cannot determine whether fires were actively suppressed even in these remote areas, therefore the terms "unburned" and "repeatedly burned" and are not meant to suggest effects due to human management decisions. The fire return intervals in our repeatedly burned stands are within the historical (i.e., pre-1900) range, which can

TABLE 1. Time since fire, physiographic data, and fire histories (based on U.S. Forest Service fire maps and on-site fire scar analysis) for unburned (UB) and repeatedly burned (RB) stands within four wilderness forest sites.

\begin{tabular}{cccccc}
\hline \hline $\begin{array}{c}\text { Site and } \\
\text { stand }\end{array}$ & $\begin{array}{c}\text { Time since } \\
\text { fire (yr) }\end{array}$ & $\begin{array}{c}\text { Mean aspect } \\
\text { (degrees) }\end{array}$ & $\begin{array}{c}\text { Mean } \\
\text { elevation }(\mathrm{m})\end{array}$ & $\begin{array}{c}\text { Mean } \\
\text { slope } \\
\text { (degrees) }\end{array}$ & $\begin{array}{c}\text { Fire years } \\
\text { since 1880 }\end{array}$ \\
\hline MC & & & & & \\
UB & $>124$ & 270.0 & 957 & 33.3 & \\
RB & 17 & 258.0 & 915 & 42.3 & $1910,1934,1981,1987$ \\
BR & & & & & \\
UB & 90 & 61.3 & 1665 & 37.3 & 1914 \\
RB & 12 & 49.3 & 1464 & 29.3 & $1914,1944,1992$ \\
MB & & & & & \\
UB & 85 & 236.0 & 1813 & 27.3 & 1919 \\
RB & 17 & 250.7 & 1536 & 32.7 & $1919,1960,1987$ \\
TW & & & & & \\
UB & 70 & 88.7 & 805 & 32.7 & 1910,1934 \\
RB & 12 & 134.7 & 869 & 33.3 & $1910,1934,1992$ \\
\hline
\end{tabular}


TABLE 2. Time since fire, mean ages of trees sampled for needle analyses and basal area increment (BAI) analyses, and mean stand densities (based on three plots per stand; see Keeling et al. 2006), for unburned (UB) and repeatedly burned (RB) stands within four wilderness forest sites.

\begin{tabular}{|c|c|c|c|c|c|}
\hline \multirow[b]{2}{*}{$\begin{array}{l}\text { Site and } \\
\text { stand }\end{array}$} & \multirow[b]{2}{*}{$\begin{array}{l}\text { Time since } \\
\text { fire }(\mathrm{yr})\end{array}$} & \multicolumn{2}{|c|}{ Mean age of trees } & \multirow{2}{*}{$\begin{array}{c}\text { Mean density } \\
\text { (Doug fir }+ \text { grand fir) } \\
\text { (trees/ha) }\end{array}$} & \multirow[b]{2}{*}{$\begin{array}{l}\text { Mean total stand } \\
\text { density (trees/ha) }\end{array}$} \\
\hline & & $\begin{array}{l}\text { Needle } \\
\text { analyses }\end{array}$ & $\begin{array}{c}\text { BAI } \\
\text { analyses }\end{array}$ & & \\
\hline \multicolumn{6}{|l|}{$\mathrm{MC}$} \\
\hline UB & $>124$ & $211(63)$ & $211(63)$ & $117(181)$ & $283(232)$ \\
\hline RB & 17 & $211(48)$ & $223(32)$ & $75(66)$ & $192(14)$ \\
\hline \multicolumn{6}{|l|}{ BR } \\
\hline UB & 90 & $291(87)$ & $330(31)$ & 492a (194) & $567 \mathrm{a}(146)$ \\
\hline $\mathrm{RB}$ & 12 & 245 (107) & 341 (41) & $25 \mathrm{~b}(25)$ & $183 b(38)$ \\
\hline \multicolumn{6}{|l|}{ MB } \\
\hline UB & 85 & 141 (19) & $338(12)$ & $50(66)$ & $325(115)$ \\
\hline RB & 17 & $278(136)$ & $360(58)$ & $42(52)$ & $267(225)$ \\
\hline \multicolumn{6}{|l|}{ TW } \\
\hline UB & 70 & $185(17)$ & $181(16)$ & 592a (298) & 600a (284) \\
\hline $\mathrm{RB}$ & 12 & $166(12)$ & $166(11)$ & $25 \mathrm{~b}(43)$ & $92 \mathrm{~b}(101)$ \\
\hline
\end{tabular}

Notes: Values in parentheses are standard deviations. Significant differences between stands for ages and stand densities $(P<0.05)$ are denoted with different letters.

be more than 25 years for mixed ponderosa pine forests in the northwest region (Arno 1980, Arno and AllisonBunnell 2002, Heyerdahl et al. 2008).

\section{Data collection}

In June and July of 2004, an access route across each stand was chosen. Access routes were divided into 10 sections of equal distance. Within each section, a location along the route was randomly determined from which the nearest ponderosa pine was sampled. Trees visibly affected by disease and insect or fire damage were excluded from the sample. At each tree, elevation, aspect, slope, GPS coordinates, and tree diameter at breast height (dbh; at $1.4 \mathrm{~m}$ ) were recorded. For needle chemistry and morphology, one exposed branch was collected from the mid canopy of every tree using a 12 gauge shotgun aimed at the basal end of the terminal branch so as to sample all leaf cohorts. A $5.7 \mathrm{~cm}$ diameter steel cylinder was used to collect four soil samples, at a distance of $3 \mathrm{~m}$ in four cardinal directions from the bole of each tree. At two sites (TW and BR), short $(5 \mathrm{~cm})$ increment cores were extracted from each tree to measure the hydrogen isotopic ratio in xylem water. At these sites, four pairs of representative soil samples for measurement of hydrogen isotopic ratio, one at shallow depth $(5-10 \mathrm{~cm})$ and one at deep depth $(65-70 \mathrm{~cm})$ were taken per burned and unburned stand. The soil and xylem water isotopic study was repeated in 2006. All soil and branch samples were placed in plastic resealable bags and stored in a cooler with ice, or in drybags submersed in cold water for the duration of each field trip. Short-increment cores were stored in watertight plastic test tubes. For age estimates and basal area growth analysis, two complete increment cores to the pith were extracted from each tree and tree diameter at coring height was recorded. Cores were taken at approximately $50 \mathrm{~cm}$ height from the ground. The two cores were taken from opposite sides of the tree, perpendicular to the direction of the slope. Four bark depth measurements were taken at coring height using a bark gauge. In 2006 and 2007, increment cores for growth analyses were extracted from additional trees at $\mathrm{BR}$ and $\mathrm{MB}$ providing additional trees at these sites for BAI analysis (sample sizes for all variables range from 6-19 trees per stand and are reported in figures).

\section{Sample processing and analysis}

Internodes separating annual needle cohorts were identified and fascicles within each cohort were removed and counted. Average needle length for each cohort was measured to the nearest millimeter, and all needles within each cohort were placed in envelopes, dried for 48 hours at $65^{\circ} \mathrm{C}$ in a drying oven, and weighed. Total needle biomass was calculated as the sum of the mass of all the needles on each branch. Ten fascicles from the one-year-old cohort were randomly selected for estimation of specific leaf area. These 10 fascicles were weighed separately and leaf area for these needles was calculated by making a digital image of the needles. Needle area was calculated from the scanned images. Average specific leaf area was calculated as total area divided by total weight. A subset of needles from the year-one cohort from each branch (one branch per tree) was selected for needle chemistry analysis. Needles were ground to a fine powder to pass a $0.3-\mathrm{mm}$ mesh, and samples were sent to the UC Davis Stable Isotope Facility for analysis ( 2 and $8 \mathrm{mg}$ of sample for $\mathrm{C}$ and $\mathrm{N}$ analyses, respectively). Needle samples were analyzed for $\% \mathrm{~N}, \mathrm{C}: \mathrm{N}$ ratio, and carbon isotopic ratio ${ }^{13} \mathrm{C}:{ }^{12} \mathrm{C}$ (expressed as $\delta^{13} \mathrm{C}$, the sample ratio minus the ratio of a known standard $\times 1000$ ). 
Soil samples were filtered and rinsed to remove large debris. When only root mass remained, conifer roots were easily distinguished based on color, size, and morphology. A subsample of roots for each tree was examined under a microscope and root tips were categorized visually as infected or not infected by mycorrhizal fungi and infection rate was expressed as percent of root tips infected. Roots were then oven-dried and weighed. The average fine root mass for each tree sampled was expressed on an area basis and divided by the stand density (see Keeling et al. 2006) in order to express the fine root content of the soil on a per-tree basis. Due to time and cost constraints, analysis of $\mathrm{H}$ isotopic ratio in soil and xylem water was done for two sites only (MB and TW) in 2004 and 2006. Samples were sent to the UC Davis Stable Isotope Facility for measurement of $\mathrm{H}$ isotopic ratio.

Increment cores were processed, measured, and crossdated, and age estimates for each tree were obtained following standard procedures (Stokes and Smiley 1968). The recent 10-year (1994-2003) basal area increment (BAI) was calculated by assuming a circular area and subtracting the inner basal area interior to 1994 from the total basal area. BAI for the two cores of each tree were averaged. To control for age-related effects on growth, trees less than 150 years old and greater than 500 years old were excluded from the BAI analysis.

\section{Statistical analyses}

Statistical analyses were carried out in the software program SPSS 16.0 (IBM, Somers, New York, USA). Variables were tested for normal distribution using a Kruskal-Wallis test and samples were tested for homogeneity of variance using Levene's test. Where necessary, variables were transformed using a log or square-root function. Differences in mean tree age between repeatedly burned and unburned stands were tested using $t$ tests. Comparison between repeatedly burned and unburned stands of needle chemistry, needle morphology, and root/mycorrhizae variables were analyzed using two-way ANOVA with site and stand (unburned and repeatedly burned) as random factors, with stand nested within site. Recent basal area increment (BAI) was tested using two-way ANCOVA with site as a random factor, stand as a fixed factor, and age as a covariate. For variables that did not pass Levene's test after transformation, nonparametric Mann-Whitney $U$ tests were used. Individual $t$ tests were used to test for significant differences between stands within sites. Depth of water sources at MB and TW in 2004 and 2006 were analyzed separately using two-way ANOVA with sample location (shallow soil, deep soil, sapwood) and stand (repeatedly burned, unburned) as fixed factors. Tests for which there were no overall significant differences between repeatedly burned and unburned stands were evaluated using post hoc power tests. Minimum detectable changes (MDC) at a Type II error threshold of $1-$ beta $=0.8$ were calculated for each test as described in Elzinga et al. (2001). Minimum detectable changes at this level of Type II error probability were converted into effect sizes using the formula: effect size $=\mathrm{MDC} /$ standard deviation. Tests that were capable of detecting an effect size of 0.75 were considered to have sufficient power.

\section{RESUlTS}

Sample sizes varied slightly for each variable measured and ranged from 6 to 19 trees per stand (sample sizes are given in figure captions). Unless indicated, all variables met ANOVA assumptions. Stand densities, tree ages, total needle biomass, fine root biomass, and recent BAI were log or square-root transformed to meet ANOVA assumptions. Otherwise, differences between repeatedly burned and unburned stands were tested using a Mann-Whitney $U$ test.

Averaged across all sites, unburned stands had higher total stand densities $\left(F_{4,23}=5.332, P=0.006\right)$ and higher densities of late succession tree species (Douglas-fir plus grand fir; $F_{4,23}=8.379, P=0.001$, Table 2). Within sites, total stand densities were significantly higher in the unburned stands at BR $\left(t_{4}=4.386, P=0.012\right.$, Table 2$)$ and TW $\left(t_{4}=2.921, P=0.043\right.$, Table 2$)$. Densities of late succession species were also significantly higher in the unburned stands at BR $\left(t_{4}=4.127, P=0.015\right.$, Table 2$)$ and TW $\left(t_{4}=4.277, P=0.013\right.$, Table 2$)$.

There were no significant overall differences between repeatedly burned and unburned stands in needle $\mathrm{N}$ content $\left(F_{4,70}=0.971, P=0.429 ;\right.$ Fig. $\left.2 \mathrm{a}\right)$ or $\mathrm{C}: \mathrm{N}$ ratio $\left(F_{4,70}=0.997, P=0.415\right.$; Fig. $\left.2 b\right)$. Needle $\mathrm{C}$ isotopic ratio was slightly higher in repeatedly burned stands overall $\left(F_{4,70}=2.997, P=0.024\right.$; Fig. $\left.2 \mathrm{c}\right)$ and recent BAI was lower in repeatedly burned stands $\left(F_{6,80}=2.581, P=\right.$ 0.025; Fig. 2d) but these results were both driven by differences at a single site, $\mathrm{MB}$, in $\mathrm{C}$ isotopic ratios $\left(t_{17}=\right.$ $3.519, P=0.003$; Fig. $2 \mathrm{c})$ and BAI $\left(t_{26}=3.259, P=\right.$ 0.003; Fig. 2d). There were no significant differences between repeatedly burned and unburned stands in the mean ages of trees used to compare needle characteristics (Mann-Whitney $U$ test, $P=0.650$, Table 2) or BAI $\left(F_{4,88}=0.990, P=0.418\right.$, Table 2$)$ and no significant differences in mean tree ages between stands within any site (Table 2).

Average needle length was greater in the unburned stand at BR $\left(t_{14}=2.553, P=0.023\right)$ but there was no significant difference across all sites $\left(F_{4,67}=2.058, P=\right.$ 0.096; Fig. 3a). Total needle biomass per branch was slightly but significantly higher in repeatedly burned stands overall $\left(F_{4,68}=2.548, P=0.047\right.$; Fig. $\left.3 b\right)$. This increase was not related to an increase in needle retention time (i.e., total number of needle cohorts). There were no significant differences between repeatedly burned and unburned stands in leaf specific area $\left(F_{4,67}=\right.$ $1.131, P=0.349$; Fig. 3c). Fine roots on a per-tree basis were higher in repeatedly burned stands overall $\left(F_{4,23}=\right.$ 3.007, $P=0.039$; Fig. 4a). This difference was driven mostly by a large, albeit nonsignificant, difference at TW 

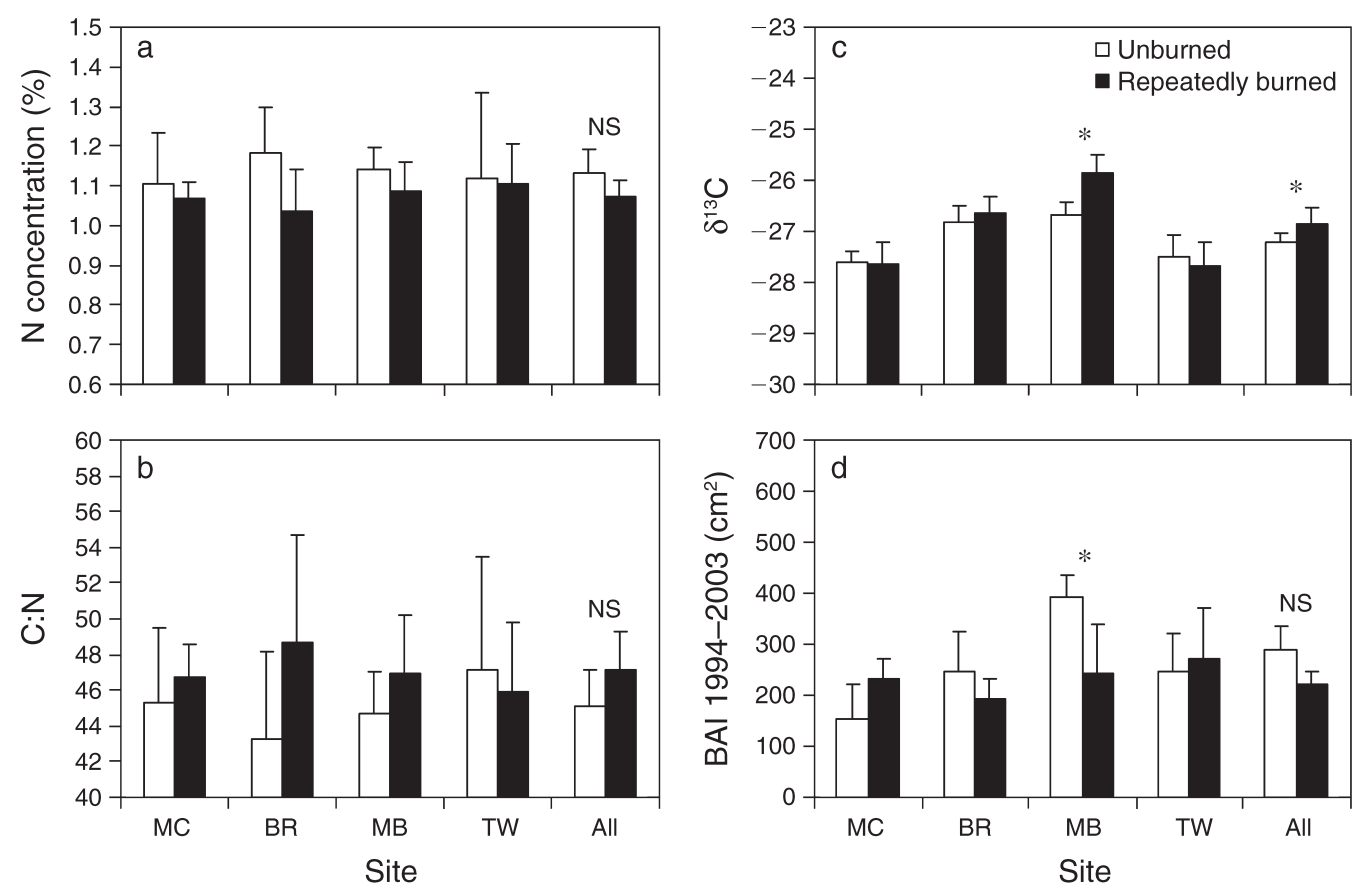

FIG. 2. (a) $\mathrm{N}$ concentration, (b) $\mathrm{C} / \mathrm{N}$, (c) $\delta^{13} \mathrm{C}$, and (d) recent basal area increment (BAI) in ponderosa pine trees in unburned stands and repeatedly burned stands at each of four sites and averaged across all sites. Sites are shown in order of decreasing time since fire in the unburned stand and decreasing difference in number of fires between the two stands (see Tables 1 and 2). Error bars are confidence intervals. Asterisks $(*)$ mark significant overall differences between unburned and repeatedly burned stands across all sites (two-way ANOVA with site as a random factor and stand nested within site as a fixed factor, $P \leq 0.05$ ) and significant differences within sites $(t$ test, $P \leq 0.05)$. NS stands for nonsignificant result that passed the post hoc power test (minimum detectable change with effect size $\leq 0.75$ with beta $\leq 0.2$ ). Sample sizes for $\mathrm{N}$ concentration, $\mathrm{C}: \mathrm{N}$, and $\delta^{13} \mathrm{C}$ are $($ site unburned, repeatedly burned): MC 16, 9; BR 10, 9; MB 9, 10; TW 9, 6. Sample sizes for BAI are: MC, 10, 9; BR, 8, 17; MB, 9, 19; $\mathrm{TW}, 10,7$.

$\left(t_{6}=3.082, P=0.166 ;\right.$ Fig. $\left.4 \mathrm{a}\right)$. There was no significant difference between repeatedly burned and unburned stands in mycorrhizal infection (Mann-Whitney $U$ test, $P=0.157$; Fig. 4b). The nonsignificant finding for mycorrhizae did not pass our criteria for sufficient power.

Differences in $\mathrm{H}$ isotopic signatures between repeatedly burned and unburned stands at TW in 2004 and MB in 2006 were tested using a Mann-Whitney $U$ test due to lack of homogeneous variances. There were no significant differences in $\mathrm{H}$ isotopic signature between repeatedly burned and unburned stands across all sample categories (surface soils, deep soils, sapwood) at $\mathrm{MB}$ in $2004\left(F_{1,2.017}=0.271, P=0.654\right.$; Fig. 5a $)$, at TW in 2004 (Mann-Whitney $U$ test, $P=0.214$; Fig. 5b), and at MB in 2006 (Mann-Whitney $U$ test, $P=0.077$; Fig. 5c) $\mathrm{H}$ isotopic signatures were higher in sapwood than in both shallow and deep soils at MB, whereas at TW sapwood $\mathrm{H}$ isotopic ratios were intermediate between isotopic signatures of shallow and deep soil samples. There were no data for repeatedly burned stands at TW in 2006.

To allow inspection of possible effects due to gradients of different fire histories across sites, sites in
Tables 1 and 2 and Figs. 2-4 are shown in order of decreasing time since fire in the unburned stand and decreasing difference in number of fires between the two stands (see Table 1). There was no evidence of gradient effects on any of the variables we studied.

\section{Discussion}

We hypothesized that mature overstory trees in stands not burned for at least 70 years would show symptoms of physiological, competition-induced stress when compared to similar trees in repeatedly burned stands. Contrary to our hypothesis, we found surprisingly little evidence of adverse effects of lack of fire on mature ponderosa pine trees for the variables we measured. The slightly lower total needle biomass per branch in unburned stands was the only result consistent with higher stress conditions in repeatedly burned stands. Four other needle variables ( $\mathrm{N}$ concentration (\%), C:N ratio, needle length, and leaf specific area) showed no significant overall differences between repeatedly burned and unburned stands. Results for needle $\delta^{13} \mathrm{C}$, and fine roots were contrary to the expectation of higher stress in unburned stands. In the case of $\delta^{13} \mathrm{C}$, the overall differences were driven by individual site responses at 

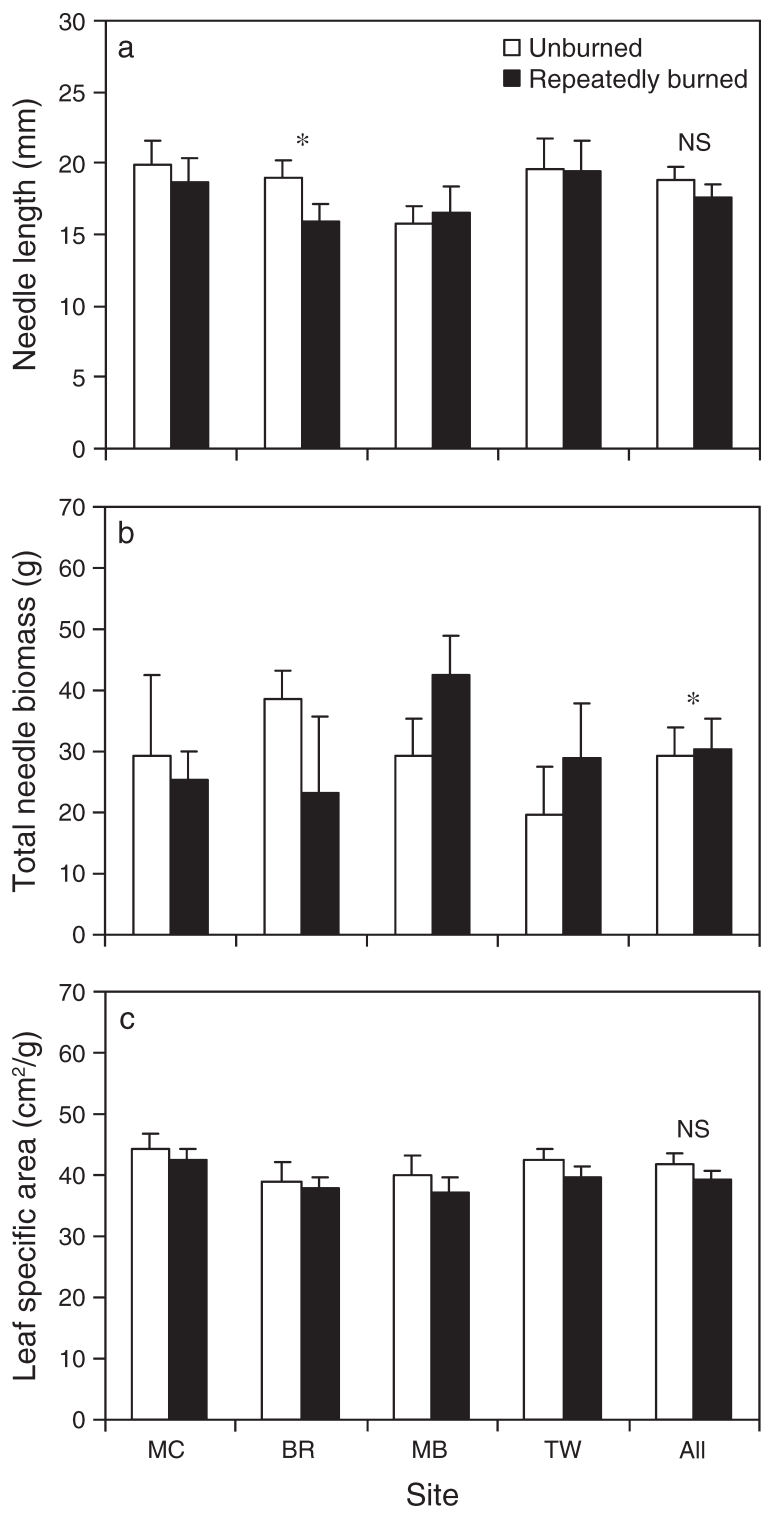

FIG. 3. (a) Needle length, (b) total needle biomass, and (c) leaf specific area in ponderosa pine trees in unburned stands and repeatedly burned stands at each of four sites and averaged across all sites. Sites are shown in order of decreasing time since fire in the unburned stand and decreasing difference in number of fires between the two stands (see Tables 1 and 2). Error bars are confidence intervals. Asterisks $(*)$ show significant overall differences between unburned and repeatedly burned stands across all sites (two-way ANOVA with site as random factor and stand nested within site as fixed factor, $P<0.05)$ and significant differences within sites $(t$ test, $P \leq 0.05)$. NS stands for nonsignificant result that passed the post hoc power test (minimum detectable change with effect size $\leq 0.75$ with beta $\leq 0.2$ ). Sample sizes for all variables (site unburned, repeatedly burned): MC, 16, 9; BR, 9, 7; MB, 9, 10; TW, 9, 6.

MB (Fig. 2c). For fine roots, the difference was very small and probably not biologically significant. There was no evidence that trees in unburned stands were tapping deeper water sources (Fig. 5) as would be predicted during water stress. Finally, although basal area growth responses varied from site to site, there was no overall difference in recent growth between trees in repeatedly burned vs. unburned stands (Fig. 2d). Based on the variables measured, our results suggest that lack of recent fire in unburned stands did not cause significant physiological stress in mature trees relative to trees in repeatedly burned stands.

To our knowledge, this is the first study to compare tree functional variables in unlogged, contemporary, frequently burned, ponderosa pine stands vs. stands not subjected to fire for most of the 20th century. By selecting stands in remote, unlogged forests we eliminated the potential confounding effects of prior logging on stand conditions, which have been shown to exacerbate the effects of fire exclusion on stand density
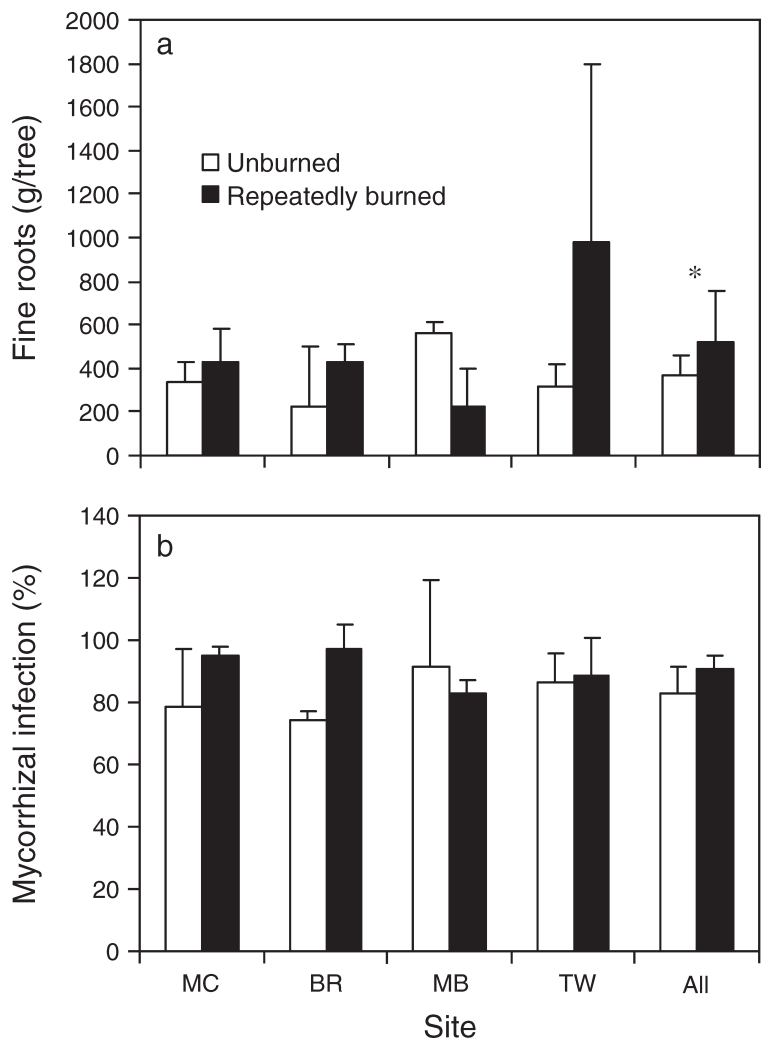

FIG. 4. (a) Mass of fine roots per tree and (b) percentage of mycorrhizal infection for roots of ponderosa pine trees in unburned stands and repeatedly burned stands at each of four sites and averaged across all sites. Sites are shown in order of decreasing time since fire in the unburned stand and decreasing difference in number of fires between the two stands (see Tables 1 and 2). Error bars are confidence intervals. Asterisks (*) mark significant overall differences between unburned and repeatedly burned stands across all sites (two-way ANOVA with site as random factor and stand nested within site as fixed factor, $P \leq$ $0.05)$ and significant differences within sites ( $t$ test, $P \leq 0.05)$. NS stands for nonsignificant result which passed the post hoc power test (minimum detectable change with effect size $\leq 0.75$ with beta $\leq 0.2$ ). Sample sizes for all variables (site, unburned, repeatedly burned): MC, 3, 4; BR, 4, 4; MB, 4, 4; TW, 4, 4 . 

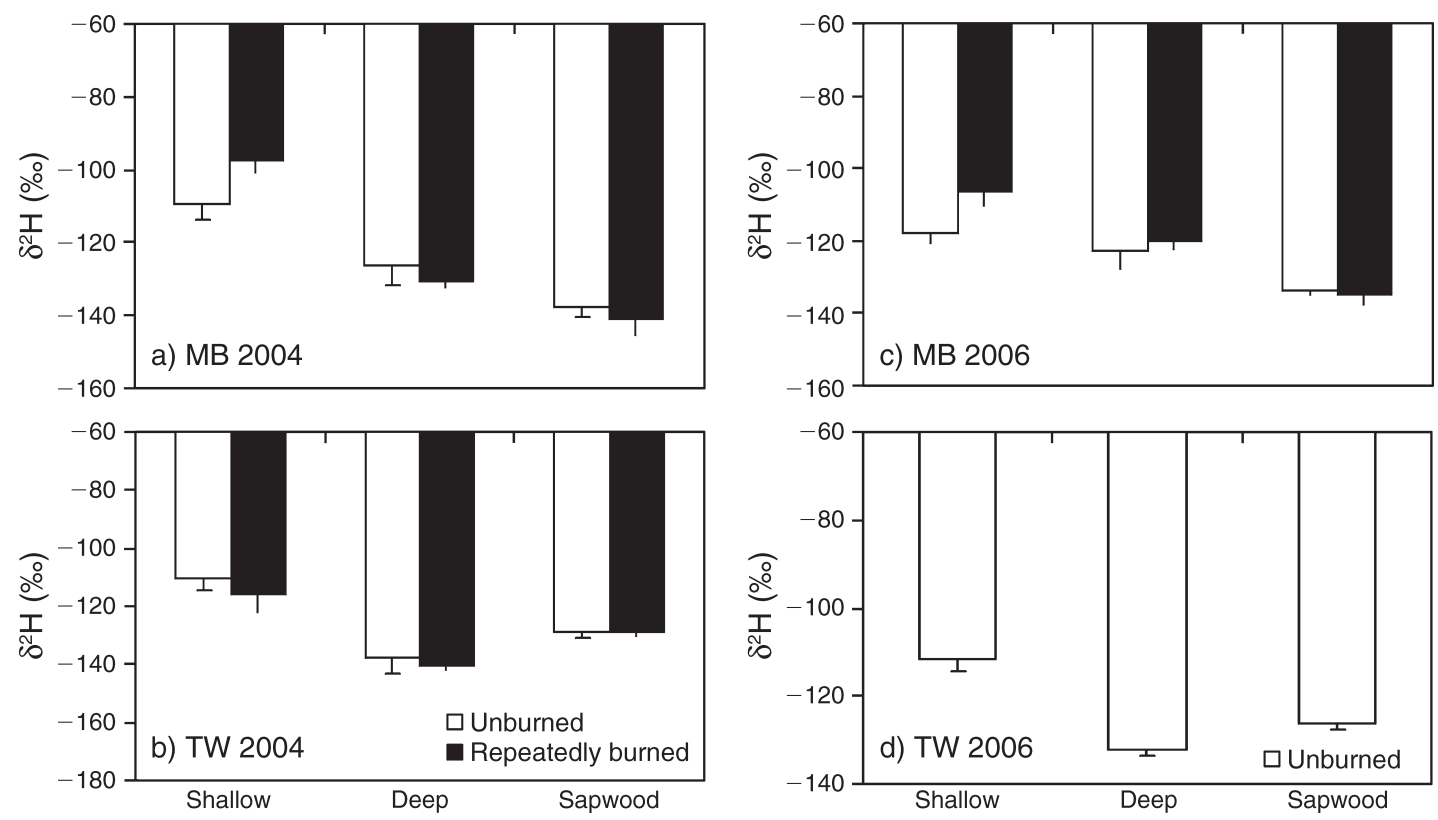

FIG. 5. Deuterium isotope ratio $\left(\delta^{2} \mathrm{H}\right)$ values in shallow soil, deep soil, and sapwood of ponderosa pine trees in unburned stands and repeatedly burned stands at (a) MB in 2004, (b) TW in 2004, (c) MB in 2006, and (d) TW in 2006. Error bars are confidence intervals. Sample sizes (shallow, deep, sapwood): MB 2004, unburned, 5, 5, 6; repeatedly burned, 4, 3, 5; TW 2004, unburned, 6, 5, 5; repeatedly burned, 5, 5, 6; MB 2006, unburned, 4, 7, 5; repeatedly burned, 5, 5, 5; TW 2006, unburned, 4, 3, 6 .

(Naficy et al. 2010). Studies in previously logged forests that test for physiological differences between repeatedly burned and unburned stands may be more likely to find larger differences between these stands. Our pairedstand sample design also allowed us to measure longterm responses in old, mature trees, rather than shortterm responses in second-growth trees. Despite higher densities and lower nitrogen availability (DeLuca and Sala 2006, Keeling et al. 2006), the dominant trees we sampled in unburned stands may have better access to light and soil resources than smaller, subdominant competitors. In contrast to our results, studies in second-growth, relatively even-aged stands, especially short-term studies before and after stand manipulations, generally record large effects due to stand density changes, because residual trees are released from the greater competitive effects between trees of the similar age and size (Donner and Running 1986, Kolb et al. 1997, Stone et al. 1999, Latham and Tappeiner 2002). Such treatments often reduce both density and overall basal area. At our sites, repeatedly burned stands had lower densities in the small size classes, but did not have significantly lower overall basal area (Keeling et al. 2006). Therefore, competitive effects on the wellestablished dominant trees in our unburned stands may have been much smaller than would be the case in manipulated studies.

The interpretation of our results deserves caution for several reasons. Finding suitable paired stands in remote unlogged forests posed a considerable challenge and unavoidably constrained our design and sampling (see
DeLuca and Sala [2006] and Keeling et al. [2006] for further discussion). Repeatedly burned stands in unlogged forests are extremely rare in the landscape and paired unburned stands are unavoidably variable in how long they have escaped fire. Even so, our design allowed the comparison of stands not burned for 70 to $>124$ years with stands that experienced repeated fire at roughly historical frequencies (from one to four fires) during the same time period. Notably, no gradientdriven pattern emerged when sites were sorted by time since fire in the unburned stand or as a function of the number of additional 20th century fires in the repeatedly burned stands. In other words, physiological stress in the unburned stands was unrelated to time since fire or number of fires missed. Our focus on remote sites also limited the number of variables we could measure. For example, we were not able to carry the heavy instruments necessary to make gas exchange measurements. However, recent basal area growth, a variable that integrates overall physiological response, did not provide evidence for more stressful conditions in unburned stands. Therefore, gas exchange differences between stands, if present, apparently were not significant enough to affect overall growth. Finally, the overall number of sites and our sample sizes within sites were limited. Ideally, more sites with paired stands and more intensive sampling within stands would increase the confidence of findings of no difference between stands. However, for the variables that we measured, power tests indicated that our sampling was adequate to detect true differences that were reasonably small with 
moderate, but acceptably low probability of failure of detection (Type II error). More research with higher sample sizes is needed in northwest ponderosa pine forests to confirm these results.

There are other inherent challenges involved in studying wildfire in unmanipulated stands (van Mantgem et al. 2001). Both fire atlas and fire scar data are susceptible to errors (Shapiro-Miller et al. 2007). Fire history from fire scars was conducted at two of our four sites: TW and MB (Heyerdahl et al. 2008; note that in Heyerdahl et al. 2008 sites are named differently: TW = TTM and $\mathrm{MB}=\mathrm{COV}$ ). Results from this analysis showed some inconsistencies with the fire atlas perimeters at one of these sites, TW, where two earlier century fires (1910 and 1934) were not recorded in the fire atlas. This discrepancy raises the possibility of fire history errors at the two sites where we do not have detailed fire scar data. However, fire atlas errors are more likely to occur for earlier century fires when the delineation and recording of fire perimeters was more imprecise than later in the century. If so, our premise that repeatedly burned stands experienced more fires than unburned stands holds true. Perhaps more importantly, repeatedly burned stands at these sites were less dense, had firescarred trees, more charcoal, and higher available $\mathrm{N}$ in the soils, which is consistent with higher fire frequency (DeLuca and Sala 2005, Keeling et al. 2006, DeLuca and Aplet 2008).

In addition, natural wildfire in unmanaged forests cannot be perfectly controlled as a "treatment" in the experimental sense. Fire severity varies between fires and fires within a given perimeter are patchy, not all areas experience fires equally, and some patches escape fire altogether (Keane et al. 2008). Therefore, trees in stands categorized as "repeatedly burned" cannot be considered a uniformly treated sample. In fact, our stratified sampling of mature trees regardless of tree-level fire effects was intended to capture this natural variability which we believe provides a more realistic measurement of stand-level effects. Of course, there is the possibility that some of our sampled trees in the repeatedly burned stands did not experience each fire directly at the base of the tree. However, fire histories constructed from a separate sample of fire-scarred trees in the unburned stands at two of our sites show that the percentage of trees that recorded a given fire within a known fire perimeter varied between $100 \%$ and $80 \%$ (Heyerdahl et al. 2008). These data are consistent with recent burn severity research showing that unburned patches generally cover between $15 \%$ and $21 \%$ of the area within fire perimeters (Keane et al. 2008). With repeated fires the probability increases that a given tree was directly challenged by fire. Therefore, we consider it highly unlikely that areas around trees in the repeatedly burned stands consistently escaped fire to an extent so as to make their conditions indistinguishable from trees in unburned stands.
Our findings raise the interesting possibility of countervailing positive effects of lack of fire and/or negative effects of frequent fire that can offset benefits of reduced competition in repeatedly burned stands. In a related study, Keeling (2009) showed that more recent fires tended to produce short-term negative growth responses in individual trees relative to old fires. These negative growth responses could be due to higher severity fires driven by changes in climate (Westerling et al. 2006), or because low-intensity fires are easier to suppress (Keane et al. 2008). Severe fires are more likely to directly harm important tissues in trees (Ryan and Frandsen 1991, Harrington 1993, Hood 2010, O'Brien et al. 2010). Because we did not systematically sample trees with visible signs of fire damage, our study was not biased toward trees more likely to exhibit this countervailing negative response. In any case, fires can injure trees without leaving durable visible signs by injuring roots or cambium (Hood 2010) or via negative effects on soil fertility (Neary et al. 1999). Although our study was not designed to elucidate all the specific mechanisms that might produce countervailing effects, the possibility of cumulative long-term negative effects of nonlethal fire on trees is an interesting area for future research (Hood 2010).

In summary, we did not observe negative effects on dominant ponderosa pine trees in stands not burned for at least 70 years relative to repeatedly burned stands. These results highlight the possibility that dominant ponderosa pine trees in uneven-aged forests are less responsive to the absence of fire than previously recognized. This may be because mature trees are more resilient to higher densities associated with lack of fire (Skov et al. 2004, 2005) and/or because the negative effects of recent fire may offset benefits of lower densities maintained by fire. With the cautions outlined above in mind, the management implications of our study may be most relevant for remote, uneven-aged, old-growth forests. Our results suggest that the ultimate replacement of ponderosa pine in unburned stands may result from increased competition in small size classes and lack of effective recruitment of ponderosa pine vs. species such as Douglas-fir. The shift of focus to subdominant trees and recruitment may imply a restoration need of retaining more diversity in smaller size classes for the long-term perpetuation of old ponderosa pine forests. In addition, a lack of detectable physiological effect in higher density, unburned stands points to the need for greater clarity with respect to the use of the term "forest health" and management strategies that invoke this concept. In second-growth, even-aged stands near human population centers, empirically established risk to property and forest resources will likely guide management strategies. In such cases, "forest health" may refer to the probability of avoiding stand-replacing disturbance, and density reduction may be desirable to protect stands from catastrophic fire or to increase the vigor of trees as a protective measure against insect 
outbreaks. However, our results suggest that responses to fire and lack of fire in old forests may be more complex and tree responses to common restoration treatments in second-growth forests may not necessarily replicate tree responses to recurrent wildfire in oldgrowth, uneven-aged forests.

\section{ACKNOWLEDGMENTS}

Special thanks to Brett Davis and Carol Miller from the Aldo Leopold Wilderness Research Institute (Missoula, Montana) for assembling the GIS data base that allowed us to identify sampling sites. The authors thank numerous individuals for support in the field and the laboratory including Alex Fajardo, Geoff Farinholt, Kate Finnegan, Megan Kosterman, Greg Peters, and Sarah Weldon. Many thanks to Emily Heyerdahl and James Riser for conducting a fire history analysis at two of our sites. This project was supported by a National Research Initiative competitive Grant no. 2002-3510712267 from the USDA Cooperative State Research, Education, and Extension Service and from the USDA Leopold Wilderness Research Institute (Forest Service Rocky Mountain Research Station) ALWRI-4901.

\section{Literature Cited}

Adams, H. D. and T. E. Kolb. 2004. Drought responses of conifers in ecotone forests of northern Arizona: tree ring growth and leaf sigma C-13. Oecologia 140:217-225.

Agee, J. K. 1993. Fire ecology of Pacific Northwest forests. Island Press, Washington, D.C., USA.

Arno, S. F. 1980. Forest fire history in the Northern Rockies. Journal of Forestry 78:460-465.

Arno, S. F. 1988. Fire ecology and its management implications in ponderosa pine forests. Pages 133-140 in D. M. Baumgartner and J. E. Lotan, editors. Ponderosa pine: the species and its management. Symposium proceedings. 1987 Sept. 29Oct 1. Spokane, Washington. Washington State University, Cooperative Extension, Pullman, Washington, USA.

Arno, S. F., and S. Allison-Bunnell. 2002. Flames in our forest. Island Press, Washington, D.C., USA.

Arno, S. F., and C. E. Fiedler. 2005. Mimicking nature's fire. Island Press, Washington, D.C., USA.

Bakker, J. D., and M. M. Moore. 2007. Controls on vegetation structure in southwestern ponderosa pine forests, 1941 and 2004. Ecology 88:2305-2319.

Biondi, F. 1996. Decadal-scale dynamics at the Gus Pearson Natural Area: evidence for inverse (a)symmetric competition? Canadian Journal of Forest Research 26:1397-1406.

Covington, W. W., and M. M. Moore. 1994a. Southwestern Ponderosa pine forest structure: changes since Euro-American settlement. Journal of Forestry 92:39-47.

DeLuca, T. H., and G. H. Aplet. 2008. Charcoal and carbon storage in forest soils of the Rocky Mountain West. Frontiers in Ecology and the Environment 6:18-24.

DeLuca, T. H., and A. Sala. 2006. Frequent fire alters nitrogen transformations in ponderosa pine stands of the inland northwest. Ecology 87:2511-2522.

Donner, B. L., and S. W. Running. 1986. Water stress response after thinning Pinus contorta stands in Montana. Forest Science 32:614-625.

Elzinga, C. L., D. W. Salzer, J. P. Gibbs, and J. W. Willoughby. 2001. Monitoring plant and animal populations. Blackwell Science, Malden, Massachusetts, USA.

Feeney, S. R., T. E. Kolb, W. W. Covington, and M. R. Wagner. 1998. Influence of thinning and burning restoration treatments on presettlement ponderosa pines at the Gus Pearson Natural Area. Canadian Journal of Forest Research 28:1295-1306.

Fettig, C. J., K. D. Klepzig, and R. F. Billings. 2007. The effectiveness of vegetation management practices for preven- tion and control of bark beetle infestations in coniferous forests of the western and southern United States. Forest Ecology and Management 238:24-53.

Fulé, P. Z., J. E. Crouse, A. E. Cocke, M. M. Moore, and W. W. Covington. 2004. Changes in canopy fuels and potential fire behavior 1880-2040: Grand Canyon National Park. Ecological Modeling 175:231-248.

Gower, S. T., K. A. Vogt, and C. C. Grier. 1992. Carbon dynamics of Rocky Mountain Douglas-fir: influence of water and nutrient availability. Ecological Monographs 62:43-65.

Harrington, M. G. 1993. Predicting Pinus ponderosa mortality from dormant season and growing season fire injury. International Journal of Wildland Fire 3:65-72.

Heyerdahl, E. K., P. Morgan, and J. P. Riser II. $2008 b$. Crossdated fire histories (1650-1900) from ponderosa pinedominated forests of Idaho and western Montana. General Technical Report, RMRS-GTR-214. USDA Forest Service Rocky Mountain Research Station, Fort Collins, Colorado, USA.

Hood, S. M. 2010. Mitigating old tree mortality in longunburned, fire-dependent forests: a synthesis. General Technical Report RMRS-GTR-238. USDA Forest Service, Rocky Mountain Research Station, , Fort Collins, Colorado, USA.

Kaufmann, M. R., C. M. Regan, and P. M. Brown. 2000. Heterogeneity in ponderosa pine/Douglas-fir forests: age and size structure in unlogged and logged landscapes of central Colorado. Canadian Journal of Forest Research 30:698-711.

Keane, R. E., J. K. Agee, P. Fule, J. E. Keeley, C. Key, S. G. Kitchen, R. Miller, and L. A. Schulte. 2008. Ecological effects of large fires on US landscapes: benefit or catastrophe? International Journal of Wildland Fire 17:696-712.

Keane, R. E., K. C. Ryan, T. T. Veblen, C. D. Allen, J. Logan, and B. Hawkes. 2002. Cascading effects of fire exclusion in Rocky Mountain ecosystems: a literature review. General Technical Report GTR-91. USDA Forest Service Rocky Mountain Research Station, Fort Collins, Colorado, USA.

Keeling, E. G. 2009. Wildfire responses and tree longevity in old-growth ponderosa pine/Douglas-fir forests. Dissertation. Department of Organismal Biology and Ecology, University of Montana, Missoula, Montana, USA.

Keeling, E. G., A. Sala, and T. H. DeLuca. 2006. Effects of fire exclusion on forest structure and composition in unlogged ponderosa pine/Douglas-fir forests. Forest Ecology and Management 237:418-428.

Kolb, T. E., J. K. Agee, P. Z. Fule, N. G. McDowell, K. Pearson, A. Sala, and R. H. Waring. 2007. Perpetuating old ponderosa pine. Forest Ecology and Management 249:141157.

Kolb, T. E., K. M. Holmberg, M. R. Wagner, and J. E. Stone. 1997. Regulation of ponderosa pine foliar physiology and insect resistance mechanisms by basal area treatments. Tree Physiology 18:375-381.

Latham, P., and J. Tappeiner. 2002. Response of old-growth conifers to reduction in stand density in western Oregon forests. Tree Physiology 22:137-146.

Laudenslayer, W. F. J., and H. H. Darr. 1990. Historical effects of logging on the forests of the Cascade and Sierra Nevada Ranges of California. Transactions of the Western Section of the Wildlife Society 26:12-23.

Naficy, C., A. Sala, E. G. Keeling, J. Graham, and T. H. DeLuca. 2010. Interactive effects of historical logging and fire exclusion on ponderosa pine forest structure in the northern Rockies. Ecological Applications 20:1851-1864.

Neary, D. G., C. C. Klopatek, L. F. DeBano, and P. F. Ffolliott. 1999. Fire effects on belowground sustainability: a review and synthesis. Forest Ecology and Management 122:51-71.

O'Brien, J. J., J. K. Hiers, R. J. Mitchell, J. M. Varner III, and K. Mordecai. 2010. Acute physiological stress and mortality 
following fire in a long-unburned longleaf pine ecosystem. Fire Ecology 6(2):1-12.

Oliver, W. W., and R. A. Ryker. 1990. Ponderosa pine. In R. M. Burns and B. H. Honkalam, editors. Silvics of North America: 1. Conifers; 2. Hardwoods. Agriculture Handbook 654. Volume 2. USDA Forest Service, Washington, D.C., USA.

Pfister, R. D., B. L. Kovalchik, S. F. Arno, and R. C. Presby. 1977. Forest habitat types of Montana. General Technical Report INT-34. USDA Forest Service, Intermountain Forest and Range Experiment Station, Ogden, Utah, USA.

Reich, P. B., M. B. Walters, and D. S. Ellsworth. 1997. From tropics to tundra: global convergence in plant functioning. Proceedings of the National Academy of Sciences USA 94:13730-13734.

Ryan, K. C., and W. H. Frandsen. 1991. Basal injury from smoldering fires in mature Pinus ponderosa Laws. International Journal of Wildland Fire 1:107-118.

Sala, A., G. D. Peters, L. R. McIntyre, and M. G. Harrington. 2005. Physiological responses of ponderosa pine in western Montana to thinning, prescribed fire and burning season. Tree Physiology 25:339-348.

Schoennagel, T., T. T. Veblen, and W. H. Romme. 2004. The interaction of fire, fuels, and climate across rocky mountain forests. BioScience 54:661-676.

Shapiro-Miller, L. B., E. K. Heyerdahl, and P. Morgan. 2007. Comparison of fire scars, fire atlases, and satellite data in the northwestern United States. Canadian Journal of Forest Research 37:1933-1943.

Skov, K. R., T. E. Kolb, and K. F. Wallin. 2004. Tree size and drought affect ponderosa pine physiological response to thinning and burning treatments. Forest Science 50:81-91.

Skov, K. R., T. E. Kolb, and K. F. Wallin. 2005. Difference in radial growth response to restoration thinning and burning treatments between young and old ponderosa pine in Arizona. Western Journal of Applied Forestry 20:36-43.

Smith, J. E., D. McKay, G. Brenner, J. McIver, and J. W. Spatafora. 2005. Early impacts of forest restoration treatments on the ectomycorrhizal fungal community and fine root biomass in a mixed conifer forest. Journal of Applied Ecology 42:526-535.

Steele, R., R. D. Pfister, R. A. Ryker, and J. A. Kittams. 1981. Forest habitat types of central Idaho. General Technical Report INT-114. USDA Forest Service, Intermountain Forest and Range Experiment Station, Ogden, Utah, USA.

Stephens, S. L. 2000. Mixed conifer and red fir forest structure and uses in 1899 from the central and northern Sierra Nevada, California. Madrono 47:43-52.

Stokes, M. A., and T. L. Smiley. 1968. An introduction to treering dating. University of Arizona Press, Tucson, Arizona, USA.

Stone, J. E., T. E. Kolb, and W. J. Covington. 1999. Effects of restoration thinning on presettlement Pinus ponderosa in northern Arizona. Restoration Ecology 7:172-182.

Sutherland, E. S. 1983. The effects of fire exclusion on growth in mature Ponderosa pine in northern Arizona. Thesis. Department of Geosciences, University of Arizona, Tucson, Arizona, USA.

van Mantgem, P., M. Schwartz, and M. B. Keifer. 2001. Monitoring fire effects for managed burns and wildfires: coming to terms with pseudoreplication. Natural Areas Journal 21:266-273.

Veblen, T. 2003. Fire regime considerations. Proceedings RMRS-P-29. USDA Forest Service, Washington, D.C., USA.

Vogt, K. A., E. E. Moore, D. J. Vogt, M. J. Redlin, and R. L. Edmonds. 1983. Conifer fine root and mycorrhizal root biomass within the forest floors of Douglas-fir stands of different ages and site productivities. Canadian Journal of Forest Research 13:429-437.

Wallin, K. F., T. E. Kolb, K. R. Skov, and M. R. Wagner. 2004. Seven-year results of thinning and burning restoration treatments on old ponderosa pines at the Gus Pearson natural area. Restoration Ecology 12:239-247.

Waring, R. H., and W. H. Schlesinger. 1985. Forest ecosystems. Academic Press, Orlando, Florida, USA.

Westerling, A. L., H. G. Hidalgo, D. R. Cayan, and T. W. Swetnam. 2006. Warming and earlier spring increase western U.S. forest wildfire activity. Science 313:940-943. 